\title{
POLA KOMUNIKASI KESEHATAN DALAM PELAYANAN DAN PEMBERIAN INFORMASI MENGENAI PENYAKIT TBC PADA PUSKESMAS DI KABUPATEN BOGOR
}

\author{
Kokom Komariah, Susie Perbawasari, Aat Ruchiat Nugraha, Heru Ryanto Budiana \\ Program Studi Ilmu Hubungan Masyarakat, Fakultas Ilmu Komunikasi, Universitas Padjadjaran
}

\begin{abstract}
ABSTRAK
Penyakit Tuberkulosis (TBC) sampai saat ini masih menjadi masalah kesehatan masyarakat karena merupakan salah satu penyakit infeksi pembunuh utama yang menyerang golongan usia produktif (15-50 tahun) dan anak-anak serta golongan sosial ekonomi lemah. Metode yang digunakan dalam penelitian ini adalah penelitian deskriptif survei. Tujuan dari penelitian ini adalah untuk mengetahui: 1) proses pelayanan kesehatan Puskesmas dalam pengendalian penyakit TBC di wilayah Kabupaten Bogor; 2) Model pemberian informasi yang dilakukan oleh Puskesmas dalam pengendalian penyakit TBC di wilayah Kabupaten Bogor; 3) pelayanan pemberian informasi kaitannya dengan tingkat pengetahuan penderita dalam menanggulangi penyakit TBC di wilayah Kabupaten Bogor. Hasil menunjukkan bahwa proses pelayanan kesehatan yang dilakukan Puskesmas Citeureup dalam pengendalian penyakit TBC mengikuti standar pelayanan puskesmas yang sudah baku. Dengan mengusung motto Pelayanan Prima, Responsif, Efektif, Strategis, Tangguh, Asih, Senyum, Sapa, Salam dan Inovatif). Model pelayanan dalm pemberian informasi dilakukan secara anterpersona yang dialogis, transaksional, sesuai model sirkuler Schramm. Pelayanan pemberian informasi secara linier dapat meningkatkan tingkat pengetahuan penderita dalam menanggulangi penyakit TBC di wilayah Kabupaten Bogor.
\end{abstract}

Kata-kata kunci: Pola komunikasi, pelayanan kesehatan, pemberian informasi dan komunikasi kesehatan

\section{COMMUNICATION PATTERNS IN HEALTH SERVICES AND INFORMATION PROVIDE ON TUBERCULOSIS DISEASE AT PUBLIC HEALTH CENTRE IN BOGOR DISTRICT}

\begin{abstract}
Until now tuberculosis disease (TBC), which infection creates a major health problem, is responsible for the high mortality rate of society in productive age of 15-50 years old, children and also the weakest social economic in Indonesia. Method used in this research is descriptive survey. The purpose of this research is to explore: 1) Puskesmas (Society Health Centre) health service process in controlling TBC disease in Bogor district; 2) Model of information dissemination developed by Puskesmas in controlling TBC in Bogor district; 3) Information dissemination service in connection with the knowledge of patient about controlling $T B C$ disease in Bogor district. Result shows that health process services done by Puskesmas at Citeureup sub-district, Bogor district, strictly follows the standard rules of Puskesmas principle in controlling TBC disease. The motto of Pelayanan Prima (prime services), Responsif (responsives), Efektif (effective), Strategis (strategic), Tangguh (tough), Asih (compassion), Senyum (smile), Sapa (greetings), Salam (addressing) dan Inovatif (innovative). Service model in delivering information is done by using a dialogic interpersonal and transactional as stated by Schramm. The information dissemination service, linearly, could improve patient's level of knowledge in controlling TBC disease in Bogor district.
\end{abstract}

Keywords: Communication pattern, health service, information dissemination and health communication

Korespondensi: Dra. Kokom Komariah, M.Si. Program Studi Ilmu Hubungan Masyarakat, Fakultas Ilmu Komunikasi, Universitas Padjadjaran, Jl. Raya Bandung-Sumedang Km.21. Email: kokom.komariah66@ yahoo.com 


\section{PENDAHULUAN}

Pembangunan bidang kesehatan yang dilakukan oleh pemerintah saat ini diarahkan untuk mencapai komitmen internasional, yang dituangkan dalam Millennium Development Goals (MDGs) yang berkaitan langsung dengan bidang kesehatan yaitu menurunnya angka kematian anak, meningkatnya kesehatan ibu, memerangi HIV-AIDS, penyakit Tubercolusis (TBC) dan Malaria serta penyakit lainnya maupun hal-hal yang secara tidak langsung dengan bidang kesehatan yaitu menanggulangi kemiskinan dan kelaparan serta mendorong kesetaraan gender dan pemberdayaan perempuan.

Indonesia merupakan salah satu negara berkembang yang memiliki angka prevalensi kasus TBC yang cukup tinggi, khususnya terdapat pada masyarakat dengan golongan ekonomi menengah ke bawah. Penyakit TBC adalah suatu penyakit infeksi yang disebabkan oleh bakteri Mikrobakterium Tuberkulosa . Bakteri ini berbentuk batang dan bersifat tahan asam sehingga dikenal juga sebagai Batang Tahan Asam (BTA) (Depkes, 2009). Penyakit TB disebabkan oleh kondisi lingkungan permukiman yang kurang sehat. Apalagi di kawasan permukiman yang padat penduduk dengan tipe rumah sehat yang tidak terpenuhi. Pada pemukiman padat penduduk dan kumuh biasanya kondisi lingkungan nya pun tidak sehat. Kemudian, selain itu intensitas pencahayaan atau sinar matahari yang sulit masuk ke dalam ruangan juga menjadi penyebab berkembangbiaknya bakteri penyebab TBC, karena sinar matahari itu akan mematikan bakteri TBC secara cepat.

Pada tahun 1995, program nasional pengendalian TBC mulai menerapkan strategi DOTS dan dilaksanakan di Puskesmas secara bertahap. Sejak tahun 2000 strategi DOTS dilaksanakan secara Nasional di seluruh fasilitas pelayanan kesehatan (Fasyankes) terutama Puskesmas yang di integrasikan dalam pelayanan kesehatan dasar.

Jawa Barat sebagai wilayah provinsi yang paling padat jumlah penduduknya memiliki tingkat kerawanan terhadap penyebaran berbagai penyakit, diantaranya yaitu penyebaran penyakit TBC. Kini penyakit TBC di Jawa Barat menjadi perhatian yang cukup ketat yang dilakukan oleh Dinas Kesehatan dikarenakan berkaitan dengan kriteria capaian indikator keberhasilan dari program Millenium Development Goal's (MDG's) yang dicapai oleh Indonesia dalam hal penanggulangan TB. Berdasarkan data yang berkenaan dengan TB, pada tahun 2012 yang lalu Indonesia telah mendapatkan penghargaan dari lembaga internasional, yaitu dari Global Health USAID kepada Pemerintah Indonesia melalui Menteri Kesehatan yang disampaikan oleh Sekjen PBB berkenaan atas upaya dalam pengendalian TBC selama ini yang dikategorikan cukup berhasil, yaitu angka kesembuhan penderita TBC mencapai $87 \%$.

Wilayah Kabupaten Bogor yang merupakan bagian dari provinsi Jawa Barat memiliki potensi penyebaran ancaman penyakit Tuberkulosis (disingkat TB atau TBC) yang cukup mengkhawatirkan. Hal ini dikarenakan Kabupaten Bogor mempunyai wilayah yang sangat luas yaitu terbagi menjadi 40 kecamatan serta secara domografis dan geografis terdiri dari wilayah kawasan industri dan kawasan pegunungan dengan jumlah penduduk yang termasuk kategori sangat padat yaitu lebih dari 5 juta orang. Alasan diatas merupakan alasan yang sangat mendukung terhadap perkembangan bakteri TBC secara cepat dan terstruktur, selain faktor kesadaran manusianya itu sendiri terhadap penyakit TBC. Apabila melihat angka prevalensi kesakitan TBC di wilayah Kabupaten Bogor termasuk kategori cukup tinggi. Angka prevalensinya mencapai 240 orang per 100.000 orang. Di tingkat provinsi Jawa Barat prevalensi kesakitannya mencapai 224 orang per 100.000 orang, dan secara Nasional adalah 107 orang per 100.000 orang. Keadaan ini menunjukkan bahwa Kabupaten Bogor pernah dinyatakan sebagai wilayah endemis TB di wilayah Jawa Barat yang cukup tinggi.

Upaya-upaya penanggulangan penyakit TBC di wilayah Kabupaten Bogor dinilai cukup maksimal namun masih terdapat pula beberapa kekurangan dalam mengantisipasi penyakit TB, yaitu diantaranya adalah penyampaian informasi dari petugas kesehatan yang kemungkinan masih dirasakan kurang optimal oleh penderita, yang terbukti masih adanya nilai di bawah $85 \%$ angka kesembuhan penderita TBC yang ada di wilayah kabupaten Bogor. Menurut Aan Suhanda ${ }^{1}$, sebagai Kasub penanggulangan TBC

1 Hasil wawancara pada tanggal 18 November 2013 
Dinas Kesehatan Kabupaten Bogor menyatakan bahwa untuk sosialisasi mengenai TBC dengan berbagai solusinya telah dilakukan secara masif langsung kepada masyarakat maupun melalui optimalisasi kader-kader kesehatan yang ada di lingkungan sekitar puskesmas.

Berdasarkan fenomena tersebut maka dapat dirumuskan bagaimana pola komunikasi kesehatan dalam pelayanan pemberian informasi mengenai penyakit TBC serta kaitannya dengan tingkat pengetahuan penderita dalam menanggulangi penyakit TBCdi wilayah Kabupaten Bogor?

Pola komunikasi merupakan model dari proses komunikasi, sehingga dengan adanya berbagai macam model komunikasi dan bagian dari proses komunikasi dapat ditemukan pola yang sesuai dan mudah digunakan dalam berkomunikasi. Proses komunikasi merupakan rangkaian dari aktivitas menyampaikan pesan sehingga diperoleh feedback dari penerima pesan. Dari proses komunikasi, timbul pola, model, bentuk dan juga bagian-bagian kecil yang berkaitan erat dengan proses komunikasi. Adapun proses komunikasi yang sudah masuk dalam kategori pola komunikasi yaitu; pola komunikasi komunikasi primer, pola komunikasi sekunder, pola komunikasi linear, dan pola komunikasi sirkular.

Pola komunikasi primer merupakan suatu proses penyampaian pikiran oleh komunikator kepada komunikan dengan menggunakan suatu simbol sebagai media atau saluran. Pola komunikasi sekunder adalah proses penyampaian pesan oleh komunikator kepada komunikan dengan menggunakan alat atau sarana sebagai media kedua setelah memakai lambang pada media pertama. Pola Komunikasi Linear, disini mengandung makna lurus yang berarti perjalanan dari satu titik ke titik lain secara lurus, yang berarti penyampaian pesan oleh komunikator kepada komunikan sebagai titik terminal. Jadi, dalam proses komunikasi ini biasanya terjadi dalam komunikasi tatap muka (face to face), tetapi juga adakalanya komunikasi bermedia. Pola komunikasi sirkular secara harfiah berarti bulat, bundar atau keliling. Dalam proses sirkular itu terjadinya umpan balik, yaitu terjadinya arus dari komunikan ke komunikator, sebaga penentu utama keberhasilan komunikasi. Dalam pola komunikasi yang seperti ini proses komunikasi berjalan terus yaitu adaya umpan balik antara komunikator dan komunikan.

Komunikasi kesehatan merupakan studi yang menekankan peranan teori komunikasi yang dapat digunakan dalam penelitian dan praktik yang berkaitan dengan promosi kesehatan dan pemeliharaan kesehatan. Komunikasi kesehatan merupakan proses untuk mengembangkan atau membagi pesan kesehatan kepada audiens tertentu dengan maksud mempengaruhi pengetahuan, sikap, keyakinan mereka tentang pilihan perilaku hidup sehat.

Definisi lain dari komunikasi kesehatan menurut Health Communication Partnership's M/MC Health Communication Materials Database ialah Seni dan teknik penyebarluasan informasi kesehatan yang bermaksud mempengaruhi dan memotivasi individu, mendorong lahirnya lembaga atau institusi baik sebagai peraturan ataupun sebagai organisasi di kalangan audiens yang mengatur perhatian terhadap kesehatan. Komunikasi kesehatan meliputi informasi tentang pencegahan penyakit, promosi kesehatan, kebijaksanaan pemeliharaan kesehatan, regulasi bisnis dalam bidang kesehatan, yang sejauh mungkin mengubah dan membaharui kualitas individu dalam suatu komunikasi atau masyarakat dengan mempertimbangkan aspek ilmu pengetahuan dan etika (Liliweri, 2007: 47).

\section{METODE PENELITIAN}

Penelitian ini bertujuan untuk melihat fenomena pola komunikasi kesehatan dalam pelayanan pemberian informasi mengenai penyakit TBC pada puskesmas di Kabupaten Bogor. Agar mendapat gambaran yang lengkap, penelitian ini menggunakan format deskriptif survey. "Penelitian ini tidak bermaksud mencari hubungan atau sebab akibat dari variabel" (Bungin, 2001: 51). Oleh karena itu pada penelian ini tidak menggunakan hipotesis penelitian, tetapi menggunakannya dalam kegiatan pengumpulan data merupakan suatu keharusan.

\section{HASIL DAN PEMBAHASAN}

Pelayanan kesehatan adalah setiap upaya yang diselenggarakan secara bersama-sama dalam suatu organisasi untuk memelihara dan meningkatkan derajat kesehatan, mencegah dan mengobati penyakit serta memulihkan kesehatan perorangan, kelompok, keluarga ataupun 
masyarakat (Asrul Aswar, 1996).

Pelayanan kesehatan di Puskesmas Citeureup tentunya mulai dirasakan oleh para pasien ketika mendaftarkan dirinya untuk melakukan pengobatan.

Para pasien ditanyakan maksud kedatangannya mau

berobat ke poli mana? Untuk pelayanan kesehatan Puskesmas Citeureupdalam penanggulangan penyakit TBC dimulai ketika pasien sudah tercatat sebagai pasien di poli TBC, artinya pasien sudah dinyatakan atau terbukti dari hasil laboratorium terindikasi penyakit TB. Poli TBC di Puskesmas Citeureup terdiri dua hari yaitu Selasa untuk TB anak-anak dan hari Rabu un- tuk TB dewasa.

Pasien TBC ini harus secara rutin melakukan pengobatan sesuai ketentuan dokter, karena pasien terindikasi TBC diharuskan untuk meminum obatnya setiap hari secara berturut-turut tidak boleh ada yang terlewatkan (bolongbolong), dan apabila ada yang terlewatkan obat harus diulang dari awal. Disini, diperlukan adanya kedisiplinan dari si pasein untuk meminum obatnya.

Komunikasi antarpersona antara petugas dan pasien terjadi ketika pasien datang berkunjung/ berobat di poli TBC setiap hari Rabu. Petugas dan pasein bertemu langsung secara tatap muka. Dengan motto PRESTASI, petugas member-

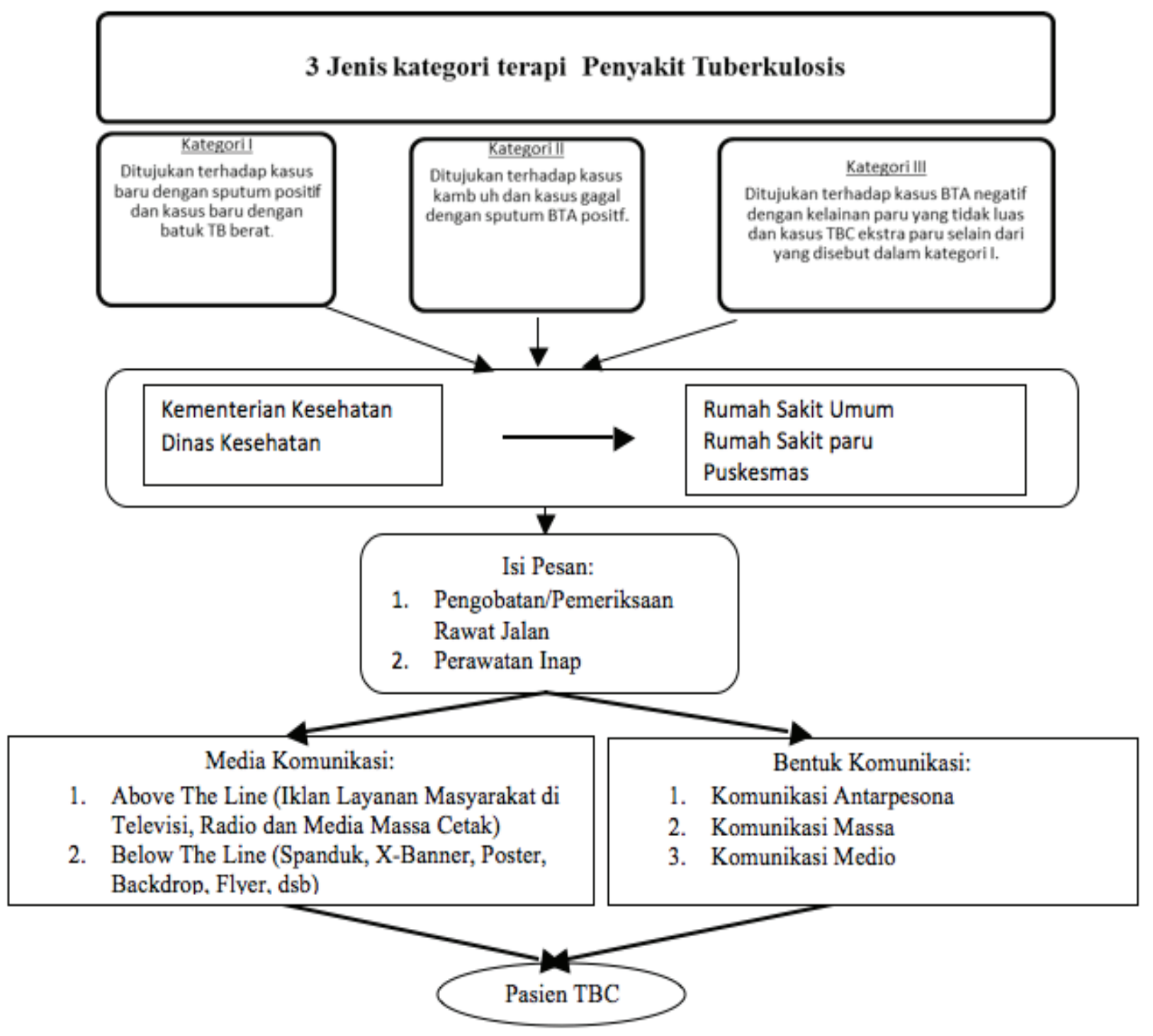

Gambar 1 Model pemberian informasi yang dilakukan oleh Puskesmas dalam penanggulangan penyakit TBC di wilayah Kabupaten Bogor 
ikan pelayanan secara prima, dimulai dengan menyampaikan 3S (senyum, sapa dan salam) kepada pasiennya.

Dalam komunikasi antarpersona tersebut biasanya terjadi secara dialogis dan transaksional, yang memulai bisa dari pasiennya terlebih dahulu atau dari petugasnya dan sebaliknya. Karenanya diantara keduanya terjadi bergantian posisi (komunikator dan komunikan, dan proses encoding dan decoding).

Menurut Erna, "Pada pertemuan awal, biasanya petugas memberikan informasi seputar penyakit TBC, mulai dari menjelaskan apa itu penyakit TBC, apa obatnya dan cara meminumnya, serta tidak kalah pentingnya menjelakan bagaimana perilaku pasien yang seharusnya guna tidak menularkannya kepada anggota keluarganya atau kepada orang lain di

lingkungannya. Intinya pasien haru diedukasi berkaitan dengan penyakitnya. Karena penyakit TBC itu dalam pengobatannya perlu kesabaran dan kedisiplinan, dimana obatnya itu tidak boleh putus. Putus berarti mengulang dan akan memperpanjang lagi waktu pengobatan".

Lebih lanjut Erna bertutur, "Selain mengedu- kasi tentang penyakit TBC, petugas juga memantau pasiennya dalam makan obat-obat yang diberikan. Petugas melakukan pengecekan silang antara data minum obat pasien dengan waktu pengambilan obat pasien. Dari sana dapat diketahui apakah pasien konsisten atau tidak minum obatnya". Bahkan menurutnya, apabila pasien berhalangan hadir di hari $\mathrm{H}$ pengobatan, bisa diambilkan atau berobat sebelum penjadwalan, supaya obat tidak sampai kehabisan.

Proses pemberian informasi penyakit TBC yang dilakukan secara antarpersona (petugas dan pasien) ini modelnya dapat ditunjukkan dengan model Schramm dalam Gambar 2.

Data deskriptif Variabel Bebas: Pelayanan Pemberian Informasi Dalam penelitian ini terdapat 5 (Lima) sub variabel bebas yaitu unsur tangible, responsiveness, reliability, empathy dan assurance.

\section{Unsur Tangible}

Sub variabel tangible terdiri dari 9 item pertanyaan. Jawaban dari 44 responden atas kuesioner sub variabel tangible dapat terlihat dalam tabel berikut ini:

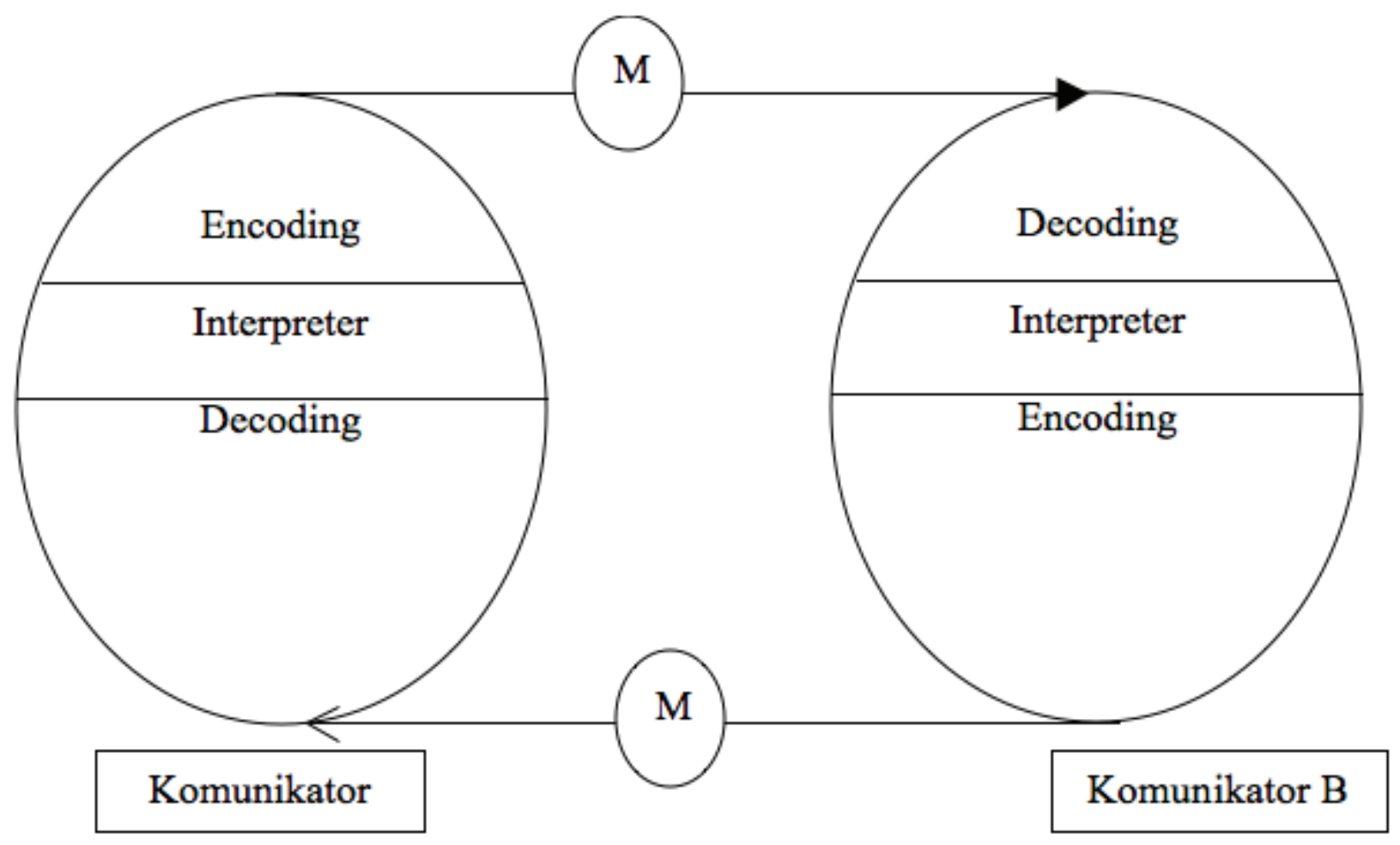


Tabel 1 Unsur Tangible

\begin{tabular}{|c|c|c|c|c|c|c|c|}
\hline \multirow{2}{*}{ No } & \multirow{2}{*}{ Pertanyaan } & \multicolumn{5}{|c|}{ Tingkat persetujuan } & \multirow{2}{*}{$\begin{array}{ll}\text { Skor } \\
\text { Total }\end{array}$} \\
\hline & & Jawaban & Bobot & $\mathrm{f}$ & Skor & $\%$ & \\
\hline \multirow{5}{*}{9} & \multirow{5}{*}{$\begin{array}{l}\text { Ketersediaan alat peraga } \\
\text { sebagai alat penunjang dalam } \\
\text { pemberian informasi TB }\end{array}$} & Sangat Baik & 5 & 3 & 15 & 6,81 & \multirow{5}{*}{150} \\
\hline & & Baik & 4 & 14 & 56 & 31,82 & \\
\hline & & Cukup Baik & 3 & 25 & 7 & 56,82 & \\
\hline & & Kurang Baik & 2 & 2 & 4 & 4,55 & \\
\hline & & Tidak Baik & 1 & 0 & 0 & 100,00 & \\
\hline \multirow{5}{*}{10} & \multirow{5}{*}{$\begin{array}{l}\text { Kelengkapan media pembe- } \\
\text { rian informasi seperti papan } \\
\text { pengumuman, edaran, brosur, } \\
\text { poster dan instruksi yang } \\
\text { ditempel }\end{array}$} & Sangat Baik & 5 & 4 & 20 & 9,09 & \multirow{5}{*}{151} \\
\hline & & Baik & 4 & 14 & 56 & 31,82 & \\
\hline & & Cukup Baik & 3 & 24 & 72 & 54,55 & \\
\hline & & Kurang Baik & 2 & 1 & 2 & 2,73 & \\
\hline & & Tidak Baik & 1 & 0 & 0 & 100,00 & \\
\hline \multirow{5}{*}{11} & \multirow{5}{*}{$\begin{array}{l}\text { Kerapihan dan kebersihan } \\
\text { pakaian seragam petugas }\end{array}$} & Sangat Baik & 5 & 4 & 20 & 9,09 & \multirow{5}{*}{172} \\
\hline & & Baik & 4 & 32 & 128 & 72,73 & \\
\hline & & Cukup Baik & 3 & 8 & 24 & 18,18 & \\
\hline & & Kurang Baik & 2 & 0 & 0 & 0 & \\
\hline & & Tidak Baik & 1 & 0 & 0 & 0 & \\
\hline \multirow{5}{*}{12} & \multirow{5}{*}{$\begin{array}{l}\text { Penampilan petugas (dokter/ } \\
\text { perawat) yang menarik }\end{array}$} & Sangat Baik & 5 & 9 & 45 & 20,45 & \multirow{5}{*}{162} \\
\hline & & Baik & 4 & 22 & 88 & 50,00 & \\
\hline & & Cukup Baik & 3 & 13 & 39 & 29,55 & \\
\hline & & Kurang Baik & 2 & 0 & 0 & 0 & \\
\hline & & Tidak Baik & 1 & 0 & 0 & 0 & \\
\hline \multirow{5}{*}{13} & \multirow{5}{*}{$\begin{array}{l}\text { Kejelasan rambu-rambu pe- } \\
\text { tunjuk ruangan pelayanan }\end{array}$} & Sangat Baik & 5 & 7 & 35 & 15,91 & \multirow{5}{*}{157} \\
\hline & & Baik & 4 & 12 & 48 & 27,27 & \\
\hline & & Cukup Baik & 3 & 24 & 72 & 54,55 & \\
\hline & & Kurang Baik & 2 & 1 & 2 & 2,27 & \\
\hline & & Tidak Baik & 1 & 0 & 0 & 0 & \\
\hline \multirow{5}{*}{14} & \multirow{5}{*}{$\begin{array}{l}\text { Kejelasan informasi tentang } \\
\text { penyakit TBC }\end{array}$} & Sangat Baik & 5 & 8 & 40 & 18,18 & \multirow{5}{*}{171} \\
\hline & & Baik & 4 & 24 & 96 & 54,55 & \\
\hline & & Cukup Baik & 3 & 11 & 33 & 25,00 & \\
\hline & & Kurang Baik & 2 & 1 & 2 & 2,27 & \\
\hline & & Tidak Baik & 1 & 0 & 0 & 0 & \\
\hline & & Sangat Baik & 5 & 2 & 10 & 4,54 & \\
\hline & & Baik & 4 & 34 & 136 & 77,27 & \\
\hline 15 & $\begin{array}{l}\text { Kebersihan ruangan pe- } \\
\text { layanan }\end{array}$ & Cukup Baik & 3 & 8 & 24 & 18,19 & 160 \\
\hline & & Kurang Baik & 2 & 0 & 0 & 0 & \\
\hline & & Tidak Baik & 1 & 0 & 0 & 0 & \\
\hline & & Sangat Baik & 5 & 3 & 15 & 6,81 & \\
\hline & & Baik & 4 & 33 & 132 & 75,00 & \\
\hline 16 & $\begin{array}{l}\text { Kenyamanan ruangan pe- } \\
\text { lavanan }\end{array}$ & Cukup Baik & 3 & 7 & 21 & 15,91 & 190 \\
\hline & & Kurang Baik & 2 & 1 & 2 & 2,27 & \\
\hline & & Tidak Baik & 1 & 0 & 0 & 0 & \\
\hline & & Sangat Baik & 5 & 4 & 20 & 9,09 & \\
\hline & & Baik & 4 & 32 & 128 & 72,72 & \\
\hline 17 & Kerapihan ruangan pelayanan & Cukup Baik & 3 & 8 & 24 & 18,19 & 172 \\
\hline & & Kurang Baik & 2 & 0 & 0 & 0 & \\
\hline & & Tidak Baik & 1 & 0 & 0 & 0 & \\
\hline
\end{tabular}


Untuk mengetahui kategori dari sub variabel tangible pemberian informasi, maka dihitung terlebih dahulu batas interval dengan cara:

- $\quad$ Skor tertinggi $=5 \times 9 \times 44$ adalah 1980

- $\quad$ Skor terendah $=1 \times 9 \times 44$ adalah 396

- $\quad$ Batas interval $=(1980-396): 5$ adalah 316,8

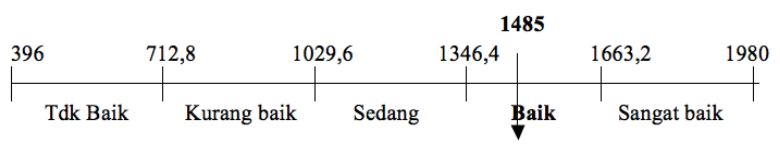

Dengan demikian indikator-indikator dari sub variabel tangible pemberian informasi TBC berada pada kategori baik. Artinya responden sudah menilai unsur tangible pemberian informasi yang meliputi : Ketersediaan alat peraga sebagai alat penunjang dalam pemberian informasi TB, Kelengkapan media pemberian informasi seperti papan pengumuman, edaran, brosur, poster dan instruksi yang ditempel, dan Kenyamanan ruangan pelayanan dinilai responden sudah baik.

Tabel 2 Unsur Responsiveness

\begin{tabular}{|c|c|c|c|c|c|c|c|}
\hline \multirow{2}{*}{ No } & \multirow{2}{*}{ Pertanyaan } & \multicolumn{5}{|c|}{ Tingkat persetujuan } & \multirow{2}{*}{$\begin{array}{l}\text { Skor } \\
\text { Total }\end{array}$} \\
\hline & & Jawaban & Bobot & $\mathrm{f}$ & Skor & $\%$ & \\
\hline \multirow{5}{*}{18} & \multirow{5}{*}{$\begin{array}{l}\text { Kecepatan petugas (dokter/ } \\
\text { perawat) dalam melayani pa- } \\
\text { sien }\end{array}$} & Sangat Baik & 5 & 7 & 35 & 15,90 & \\
\hline & & Baik & 4 & 32 & 128 & 72,74 & \\
\hline & & Cukup Baik & 3 & 4 & 12 & 9,09 & 177 \\
\hline & & Kurang Baik & 2 & 1 & 2 & 2,27 & \\
\hline & & Tidak Baik & 1 & 0 & 0 & 0 & \\
\hline \multirow{5}{*}{19} & \multirow{5}{*}{$\begin{array}{l}\text { Kesigpan petugas (dokter/ } \\
\text { perawat) dalam melayani pa- } \\
\text { sien }\end{array}$} & Sangat Baik & 5 & 7 & 35 & 15,90 & \\
\hline & & Baik & 4 & 32 & 128 & 72,74 & \\
\hline & & Cukup Baik & 3 & 4 & 12 & 9,09 & 177 \\
\hline & & Kurang Baik & 2 & 1 & 2 & 2,27 & \\
\hline & & Tidak Baik & 1 & 0 & 0 & 0 & \\
\hline \multirow{5}{*}{20} & \multirow{5}{*}{$\begin{array}{l}\text { Keterbaruan/kekinian infor- } \\
\text { masi tentang TBC }\end{array}$} & Sangat Baik & 5 & 4 & 20 & 9,09 & \\
\hline & & Baik & 4 & 13 & 52 & 29,54 & \\
\hline & & Cukup Baik & 3 & 24 & 72 & 54,54 & 150 \\
\hline & & Kurang Baik & 2 & 3 & 6 & 6,82 & \\
\hline & & Tidak Baik & 1 & 0 & 0 & 0 & \\
\hline \multirow{5}{*}{21} & \multirow{5}{*}{$\begin{array}{l}\text { Kemutakhiran alat-alat, sa- } \\
\text { rana atau fasilitas pelayanan } \\
\text { penyakit TBC }\end{array}$} & Sangat Baik & 5 & 4 & 20 & 9,09 & \\
\hline & & Baik & 4 & 13 & 42 & 29,54 & \\
\hline & & Cukup Baik & 3 & 24 & 72 & 54,54 & 140 \\
\hline & & Kurang Baik & 2 & 3 & 6 & 6,82 & \\
\hline & & Tidak Baik & 1 & 0 & 0 & 0 & \\
\hline \multirow{5}{*}{22} & \multirow{5}{*}{$\begin{array}{l}\text { Kemudahan memperoleh (ak- } \\
\text { ses) media-media informasi } \\
\text { tentang penyakit TBC }\end{array}$} & Sangat Baik & 5 & 4 & 20 & 9,09 & \\
\hline & & Baik & 4 & 16 & 64 & 36,37 & \\
\hline & & Cukup Baik & 3 & 22 & 66 & 50,00 & 153 \\
\hline & & Kurang Baik & 2 & 1 & 2 & 2,27 & \\
\hline & & Tidak Baik & 1 & 1 & 1 & 2,27 & \\
\hline
\end{tabular}

Kumulatif skor dari sembilan (5) pertanyaan

Untuk mengetahui kategori dari sub variabel responsiveness pemberian informasi, maka dihitung terlebih dahulu batas interval dengan cara:

- $\quad$ Skor tertinggi $=5 \times 5 \times 44$ adalah 1100
- Skor terendah= 1 x 5 x 44 adalah 220

- Batas interval $=(1100-220): 5$ adalah 176

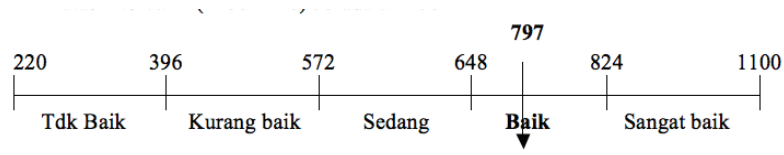


Dengan demikian indikator-indikator dari sub variabel responsiveness pemberian informasi TBC berada pada kategori baik. Artinya unsur responsiveness menurut sebagian besar responden mengenai Kecepatan petugas (dokter/perawat) dalam melayani pasien, Kesigapan petugas (dokter/perawat) dalam melayani pasien sudah baik.

Tabel 3 Unsur Reliability
Untuk mengetahui kategori dari sub variabel reliability pemberian informasi, yanga dapat dilihat pada Tabel 3, maka dihitung terlebih dahulu batas interval dengan cara:

- $\quad$ Skor tertinggi $=5 \times 3 \times 44$ adalah 660

- Skor terendah= 1 × 3 × 44 adalah 132

- Batas interval $=(660-132): 5$ adalah 105,6

\begin{tabular}{|c|c|c|c|c|c|c|c|}
\hline \multirow{2}{*}{ No } & \multirow{2}{*}{ Pertanyaan } & \multicolumn{5}{|c|}{ Tingkat persetujuan } & \multirow{2}{*}{$\begin{array}{l}\text { Skor } \\
\text { Total }\end{array}$} \\
\hline & & Jawaban & Bobot & $\mathrm{f}$ & Skor & $\%$ & \\
\hline \multirow{5}{*}{26} & \multirow{5}{*}{$\begin{array}{l}\text { Kemudahan petugas untuk } \\
\text { dihubungi pasien }\end{array}$} & Sangat Baik & 5 & 6 & 30 & 13,64 & \\
\hline & & Baik & 4 & 17 & 68 & 38,64 & \\
\hline & & Cukup Baik & 3 & 20 & 60 & 45,45 & 159 \\
\hline & & Kurang Baik & 2 & 0 & 0 & 0 & \\
\hline & & Tidak Baik & 1 & 1 & 1 & 2,27 & \\
\hline \multirow{5}{*}{27} & \multirow{5}{*}{$\begin{array}{l}\text { Kemampuan petugas mema- } \\
\text { hami keinginan dan kebutu- } \\
\text { han pasien }\end{array}$} & Sangat Baik & 5 & 3 & 15 & 6,82 & \\
\hline & & Baik & 4 & 21 & 84 & 47,73 & \\
\hline & & Cukup Baik & 3 & 19 & 57 & 43,18 & 158 \\
\hline & & Kurang Baik & 2 & 1 & 2 & 2,27 & \\
\hline & & Tidak Baik & 1 & 0 & 0 & 0 & \\
\hline \multirow{5}{*}{28} & \multirow{5}{*}{$\begin{array}{l}\text { Kemampuan petugas berko- } \\
\text { munikasi dengan pasien }\end{array}$} & Sangat Baik & 5 & 3 & 15 & 6,82 & \\
\hline & & Baik & 4 & 34 & 136 & 77,27 & \\
\hline & & Cukup Baik & 3 & 6 & 9 & 13,64 & 161 \\
\hline & & Kurang Baik & 2 & 0 & 0 & 0 & \\
\hline & & Tidak Baik & 1 & 1 & 1 & 2,27 & \\
\hline
\end{tabular}

Tabel 4 Unsur Empathy

\begin{tabular}{|c|c|c|c|c|c|c|c|}
\hline \multirow{2}{*}{ No } & \multirow{2}{*}{ Pertanyaan } & \multicolumn{5}{|c|}{ Tingkat persetujuan } & \multirow{2}{*}{$\begin{array}{l}\text { Skor } \\
\text { Total }\end{array}$} \\
\hline & & Jawaban & Bobot & $\mathrm{f}$ & Skor & $\%$ & \\
\hline \multirow{5}{*}{26} & \multirow{5}{*}{$\begin{array}{l}\text { Kemudahan petugas untuk di- } \\
\text { hubungi pasien }\end{array}$} & Sangat Baik & 5 & 6 & 30 & 13,64 & \multirow{5}{*}{159} \\
\hline & & Baik & 4 & 17 & 68 & 38,64 & \\
\hline & & Cukup Baik & 3 & 20 & 60 & 45,45 & \\
\hline & & Kurang Baik & 2 & 0 & 0 & 0 & \\
\hline & & Tidak Baik & 1 & 1 & 1 & 2,27 & \\
\hline \multirow{5}{*}{27} & \multirow{5}{*}{$\begin{array}{l}\text { Kemampuan petugas mema- } \\
\text { hami keinginan dan kebutu- } \\
\text { han pasien }\end{array}$} & Sangat Baik & 5 & 3 & 15 & 6,82 & \multirow{5}{*}{158} \\
\hline & & Baik & 4 & 21 & 84 & 47,73 & \\
\hline & & Cukup Baik & 3 & 19 & 57 & 43,18 & \\
\hline & & Kurang Baik & 2 & 1 & 2 & 2,27 & \\
\hline & & Tidak Baik & 1 & 0 & 0 & 0 & \\
\hline \multirow{5}{*}{28} & \multirow{5}{*}{$\begin{array}{l}\text { Kemampuan petugas berko- } \\
\text { munikasi dengan pasien }\end{array}$} & Sangat Baik & 5 & 3 & 15 & 6,82 & \multirow{5}{*}{161} \\
\hline & & Baik & 4 & 34 & 136 & 77,27 & \\
\hline & & Cukup Baik & 3 & 6 & 9 & 13,64 & \\
\hline & & Kurang Baik & 2 & 0 & 0 & 0 & \\
\hline & & Tidak Baik & 1 & 1 & 1 & 2,27 & \\
\hline
\end{tabular}


Tabel 5 Unsur Assurance

\begin{tabular}{|c|c|c|c|c|c|c|c|}
\hline \multirow{2}{*}{ No } & \multirow{2}{*}{ Pertanyaan } & \multicolumn{5}{|c|}{ Tingkat persetujuan } & \multirow{2}{*}{$\begin{array}{l}\text { Skor } \\
\text { Total }\end{array}$} \\
\hline & & Jawaban & Bobot & $\mathrm{f}$ & Skor & $\%$ & \\
\hline \multirow{5}{*}{29} & \multirow{5}{*}{$\begin{array}{l}\text { Para petugas memberikan waktu yang cuk- } \\
\text { up kepada pasien untuk berkonsultasi }\end{array}$} & Sangat Baik & 5 & 6 & 30 & 13,64 & \multirow{5}{*}{172} \\
\hline & & Baik & 4 & 30 & 120 & 68,18 & \\
\hline & & Cukup Baik & 3 & 6 & 18 & 13,64 & \\
\hline & & Kurang Baik & 2 & 2 & 4 & 4,54 & \\
\hline & & Tidak Baik & 1 & 0 & 0 & 0 & \\
\hline \multirow{5}{*}{30} & \multirow{5}{*}{$\begin{array}{l}\text { Sikap sopan petugas dalam melayani pa- } \\
\text { sien }\end{array}$} & Sangat Baik & 5 & 8 & 40 & 18,18 & \multirow{5}{*}{179} \\
\hline & & Baik & 4 & 31 & 124 & 70,46 & \\
\hline & & Cukup Baik & 3 & 5 & 15 & 11,36 & \\
\hline & & Kurang Baik & 2 & 0 & 0 & 0 & \\
\hline & & Tidak Baik & 1 & 0 & 0 & 0 & \\
\hline \multirow{5}{*}{31} & \multirow{5}{*}{$\begin{array}{l}\text { Ketrampilan petugas dalam melayani pa- } \\
\text { sien }\end{array}$} & Sangat Baik & 5 & 4 & 20 & 9,09 & \multirow{5}{*}{176} \\
\hline & & Baik & 4 & 36 & 144 & 81,82 & \\
\hline & & Cukup Baik & 3 & 4 & 12 & 9,09 & \\
\hline & & Kurang Baik & 2 & 0 & 0 & 0 & \\
\hline & & Tidak Baik & 1 & 0 & 0 & 0 & \\
\hline \multirow{5}{*}{32} & \multirow{5}{*}{ Pengetahuan petugas tentang penyakit } & Sangat Baik & 5 & 6 & 30 & 13,64 & \multirow{5}{*}{180} \\
\hline & & Baik & 4 & 36 & 144 & 81,82 & \\
\hline & & Cukup Baik & 3 & 2 & 6 & 4,54 & \\
\hline & & Kurang Baik & 2 & 0 & 0 & 0 & \\
\hline & & Tidak Baik & 1 & 0 & 0 & 0 & \\
\hline \multirow{5}{*}{33} & \multirow{5}{*}{$\begin{array}{l}\text { Petugas mampu memberikan pelayanan } \\
\text { sesuai harapan pasien }\end{array}$} & Sangat Baik & 5 & 7 & 35 & 15,90 & \multirow{5}{*}{163} \\
\hline & & Baik & 4 & 17 & 68 & 38,64 & \\
\hline & & Cukup Baik & 3 & 20 & 60 & 45,46 & \\
\hline & & Kurang Baik & 2 & 0 & 0 & 0 & \\
\hline & & Tidak Baik & 1 & 0 & 0 & 0 & \\
\hline \multirow{5}{*}{34} & \multirow{5}{*}{$\begin{array}{l}\text { Petugas memberi perhatian secara penuh } \\
\text { kepada setiap pasien }\end{array}$} & Sangat Baik & 5 & 6 & 30 & 13,64 & \multirow{5}{*}{163} \\
\hline & & Baik & 4 & 19 & 76 & 43,18 & \\
\hline & & Cukup Baik & 3 & 19 & 57 & 43,18 & \\
\hline & & Kurang Baik & 2 & 0 & 0 & 0 & \\
\hline & & Tidak Baik & 1 & 0 & 0 & 0 & \\
\hline & \multicolumn{6}{|l|}{ Kumulatif skor dari sembilan (6) pertanyaan } & 1033 \\
\hline
\end{tabular}

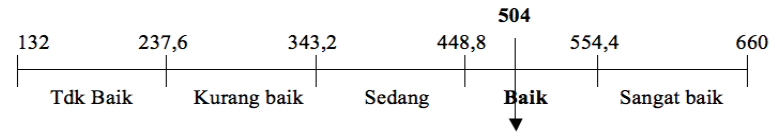

Dengan demikian, sub variabel reliability pemberian informasi TBC berada pada kategori baik

Untuk mengetahui kategori dari sub variabel empathy pemberian informasi, maka dihitung terlebih dahulu batas interval dengan cara:

- Skor tertinggi $=5 \times 3 \times 44$ adalah 660

- Skor terendah= 1 × 3 × 44 adalah 132

- Batas interval=(660-132) : 5 adalah 105,6

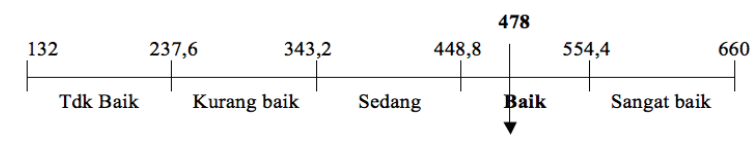

Selanjutnya untuk pembahasan mengenai empathy dapat dilihat pada Tabel 4, di mana indikator-indikator dari sub variabel empathy pemberian informasi TBC berada pada kategori baik, ini ditunjukkan dengan kemampuan petugas berkomunikasi dengan pasien.

Untuk mengetahui kategori dari sub variabel assurance pemberian informasi, maka dihitung terlebih dahulu batas interval dengan cara: 
- $\quad$ Skor tertinggi $=5 \times 6 \times 44$ adalah 1320

- Skor terendah=1 x 6 × 44 adalah 264

- Batas interval $=(660-132): 5$ adalah 211,2

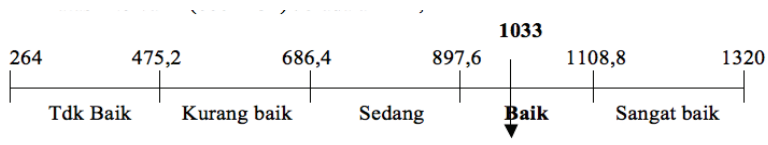

Selanjutnya untuk pembahasan mengenai assurance dapat dilihat pada Tabel 5, di mana indikator-indikator dari sub variabel assurance pemberian informasi TBC berada pada kategori baik, artinya responden menganggap hal-hal yang terkait dengan petugas misalnya tentang Para petugas memberikan waktu yang cukup kepada pasien untuk berkonsultasi, Sikap sopan petugas dalam melayani pasien dinilai baik.

\section{Tabel 6 Pengetahuan Penderita tentang Penyakit} TBC

\begin{tabular}{cccc}
\hline No & Pengetahuan & f & \% \\
\hline 1 & Tinggi & 16 & 36,36 \\
2 & Sedang & 24 & 54,55 \\
3 & Rendah & 4 & 9,09 \\
\hline & Jumlah & 44 & 100,00 \\
\hline
\end{tabular}

Sumber: Penelitian dan Pengolahan Data 2013

Berdasarkan tabel tersebut, sebagian besar penderita mempunyai pengetahuan tentang penyakit TBC yang berada pada tingkat sedang dan tinggi, dan hanya sebagian kecil $(9,09 \%)$ dari penderita yang pengetahuan tentang TBC-nya rendah. Hal tersebut disebabkan parapenderita selalu memperoleh penjelasan secara rutin tentang hal-hal yang berkaitan dengan TBC setiap kali mereka memeriksakan diri ke puskesmas dimana pada setiap hari Rabu adalah hari kusus untuk pelayanan TBC untuk Puskesmas Citeureup.
Pengetahuan merupakan aspek kognisi dan merupakan salah satu aspek dari sikap. Pengetahuan penderita tentang TBC merupakan sasaran yang hendak dicapai oleh Dinas Kesehatan melalui pemberian informasi mengenai penyakit TBC langsung kepada penderita oleh petugas puskesmas.

Pengetahuan merupakan indikator dari aspek kognisi dalam sikap yang akan menghasilkan sikap tertentu. Dengan penetahuan yang cukup mengenai penyakit TBC dan bagaimana cara menanggulanginya, diharapkan para penderita menjadi lebih paham mengenai penyakit yang dideritanya tersebut.

Komponen kognitif berisi kepercayaan seseorang mengenai apa yang berlaku atau apa yang benar bagi objek sikap. Dengan terbentuknya kepercayaan terhadap petugas yang menyampaikan informasi tentang penyakit TBC, menjadi dasar pengetahuan penderita mengenai informasi penyakit TBC.

Berdasarkan hasil penelitian diperoleh data bahwa pengetahuan penderita tentang penyakit TBC cukup tinggi, terutama pengetahuan yang berkaitan dengan cara pencegahan, penyebab, gejala, cara penularan, serta pengobatan terhadap penyakit tersebut. Sementara, yang masih kurang adalah pemahaman secara teknis yang berkaitan dengan penyakit, misalnya pengetahuan tentang pemeriksaan dahak. Pemahaman yang kurang juga yakni yang berkaitan dengan jenis obat serta jenis vaksin untuk penyakit TBC. Namun secara umum pengetahuan penderita tentang penyakit TBC sudah cukup baik.

Pada Tabel 7, dapat dilihat keterkaitan Pelayanan Pemberian Informasi tentang Penyakit TBC (X) dan tingkat pengetahuan (Y).

Hasil pengamatan menunjukkan keterkaitan antara pelayanan pemberian informasi yang sudah dinilai baik, dari segi tangible, reliability, assurance, empathy, dan responsiveness secara

Tabel 7 Keterkaitan Pelayanan Pemberian Informasi tentang Penyakit TBC (X) dan tingkat pengetahuan (Y)

\begin{tabular}{|c|c|c|c|c|c|c|c|c|}
\hline \multirow{3}{*}{$\begin{array}{l}\text { Pola Komunikasi } \\
\text { Kesehatan TBC (X) }\end{array}$} & \multicolumn{8}{|c|}{ Tingkat Pengetahuan Penderita (Y) } \\
\hline & \multicolumn{2}{|l|}{ Tinggi } & \multicolumn{2}{|c|}{ Sedang } & \multicolumn{2}{|c|}{ Rendah } & \multicolumn{2}{|c|}{ Total } \\
\hline & f & $\%$ & f & $\%$ & f & $\%$ & f & $\%$ \\
\hline Tinggi & 21 & 47,72 & 0 & 0,00 & 0 & 0,00 & 21 & 47,72 \\
\hline Sedang & 0 & 0,00 & 23 & 52,28 & 0 & 0,00 & 23 & 52,28 \\
\hline Rendah & 0 & 0,00 & 0 & 0,00 & 0 & 0,00 & 0 & 0,00 \\
\hline Total & 21 & 47,72 & 23 & 52,28 & $\mathbf{0}$ & $\mathbf{0 , 0 0}$ & 44 & 100,00 \\
\hline
\end{tabular}


linier dapat menaikkan tingkat pengetahuan. Dari kelima aspek tersebut aspek tangible, reliability, assurance memiliki keterkaitan yang tinggi dengan tingkat pengetahuan penderita tentang penyakit TBC, sementara aspek empathy, dan responsiveness memiliki keterkaitan yang sedang namun keduanya terdapat satu responden yang menjawab rendah. Disamping itu temuan peneliti memunculkan bahwa dua item pada subvariabel tangible yaitu penampilan yang menarik dan kerapihan serta kebersihan petugas (perawat dan dokter) bersifat tidak valid terkait dengan tingkat pengetahuan dari penderita terhadap TBC.

Paru-paru merupakan salah satu organ penting manusia yang bertugas sebagai tempat pertukaran oksigen yang dibutuhkan manusia dan mengeluarkan karbondioksida yang merupakan sisa hasil pernafasan yang harus dikeluarkan dari tubuh, sehingga kebutuhan manusia akan oksigen terpenuhi. Paru-paru mempunyai peranan penting bagi manusia dan mempunyai tugas yang berat dalam mengambil oksigen dari udara, belum lagi udara yang kita hirup semakin tercemar oleh berbagai bibit penyakit yang dapat menimbulkan penyakit paru-paru, salah satunya penyakit TBC.

Penyakit TBC disebabkan oleh bakteri $m y$ crobacterium tuberculosis. Penyakit ini dapat menular melalui percikan ludah saat penderita batuk. Penyakit ini ditandai gejala seperti batuk berdahak yang lebih dari tiga minggu atau batuk yang mengeluarkan darah.

TBC menyebar melalui udara dan ditularkan melalui batuk dan bersin. Proses penularan terjadi ketika seorang yang memiliki penyakit tubercolusis aktif batuk atau bersin hingga menyebarkan kuman ke udara. Kuman tersebut terhirup oleh orang yang berada didekatnya dan mengakibatkan orang tersebut terinfeksi kuman TBC.

Menurut Prayitno \& Erman Amti (2004: 259260) layanan informasi adalah kegiatan memberikan pemahaman kepada individu-individu yang berkepentingan tentang berbagai hal yang diperlukan untuk menjalani suatu tugas atau kegiatan, atau untuk menentukan arah suatu tujuan atau rencana yang dikehendaki. Dengan demikian, layanan informasi itu pertama-tama merupakan perwujudan dari fungsi pemahaman dalam bimbingan dan konseling.

Menurut Budi Purwoko (2008: 52) penyaji- an informasi dalam rangka program bimbingan ialah kegiatan membantu seeorang dalam mengenali lingkungannya, terutama tentang kesempatan-kesempatan yang ada didalamnya, yang dapat dimanfaatkan seseorang baik untuk masa kini maupun masa yang akan datang. Penyajian informasi itu dimaksudkan untuk memberikan wawasan kepada para seseorang sehingga ia dapat menggunakan informasi itu baik untuk mencegah atau mengatasi kesulitan yang dihadapinya, serta untuk merencanakan masa depan. Perencanaan kehidupan ini mencakup, kehidupan dalam studinya, dalam pekerjaannya, maupun dalam membina keluarga.

Sedangkan Winkel \&Sri Hastuti (2006: 316317) menjelaskan bahwa layanan informasi adalah usaha untuk membekali para seseorang dengan pengetahuan tentang data dan fakta dibidang tertentu, supaya mereka dengan belajar tentang lingkungan hidupnya lebih mampu mengatur dan merencanakan kehidupannya sendiri. Dari beberapa pengertian tentang layanan informasi diatas dapat diambil kesimpulan bahwa layanan informasi adalah suatu kegiatan atau usaha untuk membekali para seseorang tentang berbagai macam pengetahuan supaya mereka mampu mengambil keputusan secara tepat dalam kehidupannya.

Adapun metode layanan informasi menurut Prayitno \&Erman Amti (2004: 269-271) Pemberian informasi kepada seseorang dapat dilakukan dengan berbagai cara sebagai berikut:

Ceramah. Ceramah merupakan metode pemberian informasi yang paling sederhana, mudah dan murah, dalam arti bahwa metode ini dapat dilakukan hampir oleh setiap petugas.

Diskusi. Penyampaian informasi pada seseorang dapat dilakukan melalui diskusi. Diskusi semacam ini dapat diorganisasikan baik oleh petugas sendiri mapun oleh konselor.

Buku panduan. Buku-buku panduan (seperti buku panduan kesehatan) dapat membantu seseorang dalam mendapatkan informasi yang berguna.

Berdasarkan hasil penelitian diketahui bahwa tangibilitas pelayanan informasi yang diberikan oleh petugas kesehatan menunjukkan keterkaitan yang tinggi dengan tingkat pengetahuan pasien mengenai penyakit TBC. Dengan demikian informasi mengenai penyakit TBC yang sudah diberikan oleh petugas pelayann telah memenuhi syarat sebagai informasi mengacu pada 
definisi informasi dari Wilbur Scrhamm, yaitu: segala sesuatu yang mengurangi ketidakpastian atau mengurangi jumlah kemungkinan alternatif dalam situasi (Rakhmat, 2007: 223).

Artinya, tingkat pengetahuan yang dimiliki pasien mengenai penyakit TBC dapat disebabkan oleh adanya informasi yang diberikan petugas pelayanan, dan mampu mengurangi ketidakpastian yang dimiliki pasien dalam menangani penyakit TBC yang diterimanya. Contohnya: pasien menjadi memiliki pengetahuan mengenai cara-cara atau langkah-langkah yang harus mereka lakukan agar mereka dapat segera terbebas dari penyakit tersebut.

Selanjutnya, jaminan pelayanan informasi yang diberikan petugas pelayanan kesehatan, meliputi sikap yang sopan yang diberikan saat memberikan pelayan kesehatan bagi pasien TBC. Sikap sopan dan santun yang ditunjukkan petugas pelayanan kesehatan memberikan kesan bahwa petugas pelayanan memiliki kemauan atau niat baik dalam memberikan pelayanan kesehatan bagi pasien. Faktor kemauan dipengaruhi oleh kecerdasan, dan energi yang diperlukan untuk mencapai tujuan (Rakhmat, 2007: 43).

Berikutnya faktor keterandalan, faktor akurasi pemberian diagnosis yang diberikan petugas pelayanan kesehatan meningkatkan pengetahuan pasien mengenai kondisi penyakit yang dideritanya. Akurasi hasil diagnosis meningkatkan tingkat keterpercayaan pasien terhadap petugas pelayanan kesehatan. Hal ini sesuai dengan penyataan bahwa kepercayaan memberikan perspektif pada manusia dalam mempersepsi kenyataan dan memberikan dasar pengambilan keputusan (Rakhmat, 2007: 42).

Kecepatan dan kesigapan dalam melayani pasien, kemutakhiran alat-alat dan fasilitas pelayanan serta kemudahan memperoleh atau mengakses media informasi yang merupakan indikator dari unsur responsiveness telah dilakukan petugas dengan baik, tetapi belum dapat meningkatkan pengetahuan pasien secara signifikan. Menurut Rakhmat "Orang akan menerima pengaruh karena perilaku yang dianjurkan itu esuai dengan sistem nilai yang dimilikinya. Kita menerima gagasan, pkiran, atau anjuran orang lain, karena gagasan, pikiran, atau anjuran tersebut berguna untuk memecahkan masalah, menunjukkan arah, atau dituntut oleh sistem nilai kita.” (Rakhmat. 2007: 256)
Kemudahan petugas untuk dihubungi pasien, kemampuan dalam memahami keinginan dan kebutuhan pasien, serta kemampuan petugas berkomunikasi dengan pasien merupakan rasa empati petugas terhadap pasien, tetapi rasa empati tersebut belum dapat meningkatkan pengetahuan pasien tentang penyakit TBC secara signifikan artinya empati memiliki keterkaitan yang rendah dengan tingkat pengetahuan. Hal tersebut sesuai dengan pendapat Simon yang menyatakan bahwa "Ada hubungan positif antara kesamaan dengan rasa percaya dan hormat, tetapi hubungannya lemah" (dalam Rakhmat, 2007: 264). Sementara menurut Roger "Orang mudah berempati dan merasakan perasaan orang lain yang dipandangnya sama dengan mereka juga menunjukkan bahwa kesamaan antara komunikator dan komunikate memudahkan terjadinya perubahan pendapat" (dalam Rakhmat, 2007: 262).

\section{SIMPULAN}

Proses pelayanan kesehatan Puskesmas dalam penanggulangan penyakit $\mathrm{TBC}$ di wilayah Kabupaten Bogor, khususnya di wilayah Citeureup sudah berjalan sesuai standar pelayanan puskesmas. Pelayanan poli TBC diadakan pada setiap hari Rabu. Dengan mengusung motto pelayanan PRESTASI.

Model pemberian informasi yang dilakukan oleh Puskesmas dalam penanggulangan penyakit TBC di wilayah Kabupaten Bogor, khususnya di wilayah Citeureup sudah memenuhi kebutuhan informasi bagi petugas dan pasien. Bentuk komunikasi dalam pemberian informasi antarpersona dan model komunikasi sirkuler.

Pelayanan pemberian informasi tentang penyakit TBC di wilayah Kabupaten Bogor, khususnya di wilayah Citeureup sudah baik, hal ini dapat dilihat dari pengetahuan penderita yang cukup tentang penyebab, gejala, cara pencegahan, dan pengobatan terhadap penyakit TBC.

Sedangkan saran dari penelitian ini antara lain:

Berdasarkan hasil penelitian menunjukkan bahwa pelayanan dari petugas dan pengetahuan penderita tentang penyakit TBC sudah cukup baik. Namun ternyata masih ditemukan adanya tingkat kegagalan yang cukup significan yaitu $25 \%$. Hal ini disebabkan kurangnya kedisiplinan penderita dalam meminum obat. Untuk 
itu petugas selalu mengingatkan pasiennya untuk minum obat secara teratur

Untuk lebih meningkatkan pelayanan kesehatan hendaknya, aspek keterjangkauan tidak melulu dari sudut biaya. Tetapi mewujudkan keadaan seperti ini harus dapat diupayakan pendekatan sarana pelayanan kesehatan dan biaya kesehatan diharapkan sesuai dengan kemampuan ekonomi masyarakat.

\section{DAFTAR PUSTAKA}

Ahmad, A. S. (2006). Panduan komunikasi kesehatan. Yogyakarta: Indarti.

Azwar, S. (2005). Sikap manusia, teori dan pengukurannya. Yogyakarta: Penerbit Pustaka Belajar.

Azwar, A. (1996). Pengantar administrasi kesehatan (Edisi Ketiga). Jakarta: Binarupa Aksara

Baskoro, A. (2008). Komunikasi kesehatan. Yogyakarta: Banyu Media.

Bungin, B. (2001). Metode penelitian kuantitatif dan kualitatif. Yogyakarta. Gajahmada Press.
Graeff, A. J., dkk. (1996). Komunikasi dalam kesehatan dan perubahan perilaku. Yogyakarta: Gadjah Mada University Press.

Moeleong, Lexy. (2006). Penelitian kualitatif. Bandung: Remaja Rosda Karya.

Liliweri, Alo. (2007). Dasar-dasar komunikasi antarbudaya. Yogyakarta: Pelajar Pustaka.

Prayitno \& Amti, Erman. (2004). Dasar-dasar $B K$. Jakarta: Rineka Cipta.

Purwoko, Budi.(2008). Organisasi dan managemen bimbingan konseling. Surabaya: Unesa University Press.

Rakhmat, J. (2004). Metode penelitian komunikasi. Bandung: Remaja Rosdakarya. . (2007). Psikologi komunikasi. Bandung: Remaja Rosdakarya.

Sugiyono. (2013). Metode penelitian manajemen pendekatan: kuantitatif, kualitatif, kombinasi, penelitian tindakan dan penelitian evaluasi. Bandung: Alfabeta.

Winkel, W. S. \& Hastuti, S. (2006). Bimbingan dan konseling di institusi pendidikan. Yogyakarta: Media Abadi

Kabupaten Bogor. Diakses dari http://dinkes. bogorkab.go.id 